\title{
Playing the 'game' of transparency and accountability in Kyrgyzstan's resource governance
}

Citation for published version (APA):

Moldalieva, J. (2020). Playing the 'game' of transparency and accountability in Kyrgyzstan's resource governance. [Doctoral Thesis, Maastricht University]. ProefschriftMaken.

https://doi.org/10.26481/dis.20200930jm

Document status and date:

Published: 01/01/2020

DOI:

10.26481/dis.20200930jm

Document Version:

Publisher's PDF, also known as Version of record

\section{Please check the document version of this publication:}

- A submitted manuscript is the version of the article upon submission and before peer-review. There can be important differences between the submitted version and the official published version of record.

People interested in the research are advised to contact the author for the final version of the publication, or visit the DOI to the publisher's website.

- The final author version and the galley proof are versions of the publication after peer review.

- The final published version features the final layout of the paper including the volume, issue and page numbers.

Link to publication

\footnotetext{
General rights rights.

- You may freely distribute the URL identifying the publication in the public portal. please follow below link for the End User Agreement:

www.umlib.nl/taverne-license

Take down policy

If you believe that this document breaches copyright please contact us at:

repository@maastrichtuniversity.nl

providing details and we will investigate your claim.
}

Copyright and moral rights for the publications made accessible in the public portal are retained by the authors and/or other copyright owners and it is a condition of accessing publications that users recognise and abide by the legal requirements associated with these

- Users may download and print one copy of any publication from the public portal for the purpose of private study or research.

- You may not further distribute the material or use it for any profit-making activity or commercial gain

If the publication is distributed under the terms of Article $25 \mathrm{fa}$ of the Dutch Copyright Act, indicated by the "Taverne" license above, 


\section{Dissertation summary}

Transparency and accountability remain central to the global agenda on good governance in resource sectors, such as extractives. Policy discussions have evolved around unlocking the potential of the extractives sector to support inclusive development through addressing transparency and accountability as a cross-cutting theme in governance. This dissertation examines how global and neoliberal notions, such as transparency and accountability, are deployed in settings with weak legal institutions, neopatrimonial relations, and moments of political stability and instability. It advances a research agenda on how discourses and practices of non-elite communities shape the multiple meanings and enactments of transparency and accountability in natural resource governance. It also points to the need to explore how and why communities exert their "agency" in governing natural resources within post-Soviet contexts.

Chapter 1 presents the research inquiry and the outline of the dissertation. It indicates that the existing approaches to studying transparency and accountability neglect, for the most part, three primary issues: (neo)liberal comingling with illiberal and authoritarian notions; the role of (non-elite) societal actors; and accounts of everyday politics, which move beyond formal institutions. These three primary issues inform the focus of this research. This dissertation interrogates how and what kind of transparency and accountability discourses and practices emerge in the societal domain of Kyrgyzstan's extractive sector. It provides in-depth elucidation of the views held and the actions taken by (non-elite) communities related to transparency and accountability in resource governance. In exploring these, the dissertation unveils the conditions facilitating transparency and accountability in Kyrgyzstan's resource governance.

Chapter 2 provides a historical context of transparency and accountability at global and national levels. It presents the characteristics of transparency and accountability and situates the study within the global and national policy discussions of transparency and accountability in the extractives sector. The reviewed literature focuses on transparency and accountability in the public realm. Transparency and accountability are studied as intertwined concepts and processes. The chapter identifies the limitations of existing research, mostly focusing on the need to study transparency and accountability as daily discourses and practices that emerged at the nexus of power, social relations, and endogenous processes. It further situates the study within the political regime of Kyrgyzstan, engaging in discussions about neopatrimonialism and the new theoretical moves 
led by anthropologists that define politics to be found at the margins. The chapter contextualizes the research by deliberating on contemporary politics of Kyrgyzstan and transparency and accountability related initiatives in the country, and specifically within the country's extractives sector.

Chapter 3 presents a theoretical and conceptual approach to studying transparency and accountability. The dissertation employs social constructionism to examine transparency and accountability as discourses and practices, socially constructed by actors. It argues that both elites and non-elites (co)produce and reproduce different discourses and practices of transparency and accountability in governing natural resources. The chapter utilizes the theoretical lenses of minor politics to sharpen its focus on the political agency of (non-elite) communities and their engagement in transparency and accountability. It is, nevertheless, guided by an inductive approach to research questions at stake in the under-studied region. It analytically distinguishes the logic of transparency and accountability into two forms: substantive and instrumental use of transparency and accountability. Political games evolve across and within groups around the substantive use of transparency and accountability for a common (public) good or the instrumental use of transparency and accountability to pursue private benefits. Within such political games, the power positions of actors, the existing political-economic opportunities, and the degree of political (in)stability contribute to dynamic constructions of transparency and accountability in resource governance.

Chapter 4 introduces the research design and methodology for data collection and analysis. The dissertation shapes the research design based on the theoretical and conceptual discussions in Chapter 3. It is inspired by a practice-based approach, rooted in anthropological work, and designed to be an exploratory qualitative case study to uncover dynamics of transparency and accountability and their daily discourses and practices. The chapter provides the background description of two mining communities in Kyrgyzstan, Aral and Orlovka, and explains their selection as case study communities for this research. The research predominantly involves the use of interviews in data collection, complemented with document review and observations. It uses inductive and deductive approaches in thematic data analysis to ensure a symbiosis between the empirical and theoretical sections of this dissertation. The chapter also provides insights about researching Kyrgyzstan's mining communities.

Chapter 5 focuses on the discourses of transparency and accountability in Kyrgyzstan's resource governance. It presents empirical findings related to the first research question: what are the discourses on transparency and accountability enacted by actors within the resource governance space of Kyrgyzstan's extractive 
sector? It adopts a critical perspective to explore how transparency and accountability are constructed in Kyrgyzstan's resource governance. The chapter identifies six discourses of transparency and accountability in the two case study communities: local livelihoods, social justice, right to know, direct engagement, financial and environmental reporting, and legislative changes. It discusses the variations in transparency and accountability discourses by analyzing their substantive and instrumental use, and how such constructions converge and diverge across actors within the two study communities. The cross-case analysis unveils more instrumental discourses of transparency and accountability in Orlovka (e.g., direct engagement and social justice) and more substantive discourses of transparency and accountability in Aral (e.g., right to know and social justice).

Chapter 6 focuses on community practices of transparency and accountability in Kyrgyzstan's resource governance. It interrogates how discourses of transparency and accountability translated into practices. The analysis herein explores the political game strategies deployed by actors within the case study communities. It identifies three main strategies: publicly acknowledging the patron(s), establishing networks, and launching social mobilization. The chapter illustrates the substantive and instrumental deployment of transparency and accountability. It discusses how the interactions of actors are multi-purposive rather than being solely focused on producing more transparent and accountable resource governance. The context of weak institutions, neopatrimonial relations, and moments of political (in)stability shape the exercise of non-elite agency and their pursuits of transparency and accountability in both case study communities. The cross-case analysis reveals that Orlovka is a site where networked actor interactions and social mobilization for transparency and accountability are part of a non-elite strategy to seize power (i.e., the instrumental practice of transparency and accountability). The analysis suggests that Aral is a site where some substantive practices of transparency and accountability, framed more radically as "with the people," initially emerge on an ad-hoc basis. However, they do not translate into fully-fledged actions directed to delivering transparent and accountable practices within the resource governance space. The dissertation asserts that transparency and accountability are not themselves prime values of politics but reflective of the patterns of contestations between elites and non-elites.

Chapter 7 concludes the dissertation by synthesizing key empirical findings and summarizing the limitations and contributions of the research to future research and policymaking. The dissertation recognizes that to make sense of how global discourses, such as transparency and accountability, are contextualized, there is a need to unpack notions based on empirical inquiries and design policies based on 
realities on the ground. It suggests utilizing adaptive policymaking to account for the dynamic environment of resource governance and translate transparency and accountability discourses into collective practices. It places power-sharing mechanisms at the heart of transparency and accountability policies to enhance the continuity of actor interactions around transparent and accountable resource governance. Policy implementation should prioritize ensuring ownership of solutions by all actors along the policy and extractives value chains. The dissertation calls for re-envisioning transparency and accountability as a social process, not only as a political-economic project. This will contribute to delivering transparency and accountability as social experiences that promote (self-)reflection and direct governance. 